\title{
Pleomorphic Adenoma of the Cheek: Case Report of a Relatively Rare Localization
}

\author{
Yanak Pleomorfik Adenomu: Nadir Yerleșimli Bir Olgu Sunumu
}

\author{
İdris ÇıIdır \\ Department of Ear, Nose and Throat Diseases, Karaman State Hospital, Karaman, Turkey
}

\begin{abstract}
The pleomorphic adenoma is a tumor of epithelial origin. This tumor, which is also termed as 'benign mixed tumor', usually originates from the minor or major salivary glands. Neoplasms of the salivary glands are responsible for less than $1 \%$ of all tumors and $3-5 \%$ of all head and neck tumors. Pleomorphic adenoma (PA) is the most common tumor of the salivary gland. While the majority of PAs originate from the parotid gland, a small percentage are found in other regions. Treatment of pleomorphic adenoma is total surgical removal of the tumor. In this case report, we present the diagnosis and treatment of an 80-year-old male with a pleomorphic adenoma, and discuss the literature on this topic.
\end{abstract}

Key words: minor salivary tumor; pleomorphic adenoma; parotid gland

\section{ÖZET}

Pleomorfik adenom epitelyal kökenli bir tümördür. Selim mikst tümör olarak da adlandırılan bu tümör, minör veya majör tükürük bezlerinden kaynağını almaktadır. Tükürük bezlerinin neoplazmları tüm tümörlerin \%1'inden azını, aynı zamanda tüm baș ve boyun tümörlerinin \%3-5'inden sorumludur. Pleomorfik adenom tükürük bezinin en yaygın tümörüdür. Çoğunluk parotis bezinden kaynaklanırken, sadece küçük bir yüzdesi diğer bölgelerde ortaya çıkar. Pleomorfík adenom'un tedavisi cerrahi olarak tümörün çıkartılmasıdır. Biz 80 yașındaki erkek bir pleomorfik adenom olgusunu takdim ettik ve bu bağlamda iyi huylu minör tükürük bezi tümörlerini literatür çerçevesinde gözden geçirdik.

Anahtar kelimeler: minör tükürük bezi tümörleri; pleomorfik adenom; parotis bezi

\section{Introduction}

Pleomorphic adenoma (PA) is the most common benign salivary gland tumor in both children and adults. It accounts for approximately $3-10 \%$ of all head and neck neoplasms ${ }^{1}$. In most series, PA represents up to $45-75 \%$ of all salivary gland neoplasms ${ }^{2}$. These tumors usually occur around $40-60$ years of age and $85 \%$ of the tumors are located in the parotid gland and generally in the superficial lobe. When the pleomorphic adenomas of the minor salivary glands are evaluated, 65\% are found to be located on the hard palate, $15 \%$ on the cheek, and $10 \%$ are distributed between the tongue, base of the oral cavity, and also several other very rare regions. Approximately 3\% of pleomorphic adenomas undergo malignant degeneration, the rest remain benign. Histologically, despite having an epithelial origin, various different cell types are observed in cases of PA due to their differentiation characteristics ${ }^{3}$. Treatment options vary according to the location of the tumor; however, complete removal of the tumor as a single block along with its capsule is of the essence in all procedures. Although pleomorphic adenoma of the cheek is relatively rare, it should be considered in the differential diagnosis of tumors located in this region. We hereby present a case with a PA located on the cheek and discuss current literature on the diagnosis and treatment approaches to minor salivary gland tumors.

\section{Case Report}

An 80-year-old male patient applied to our outpatient clinic complaining from a slowly growing 


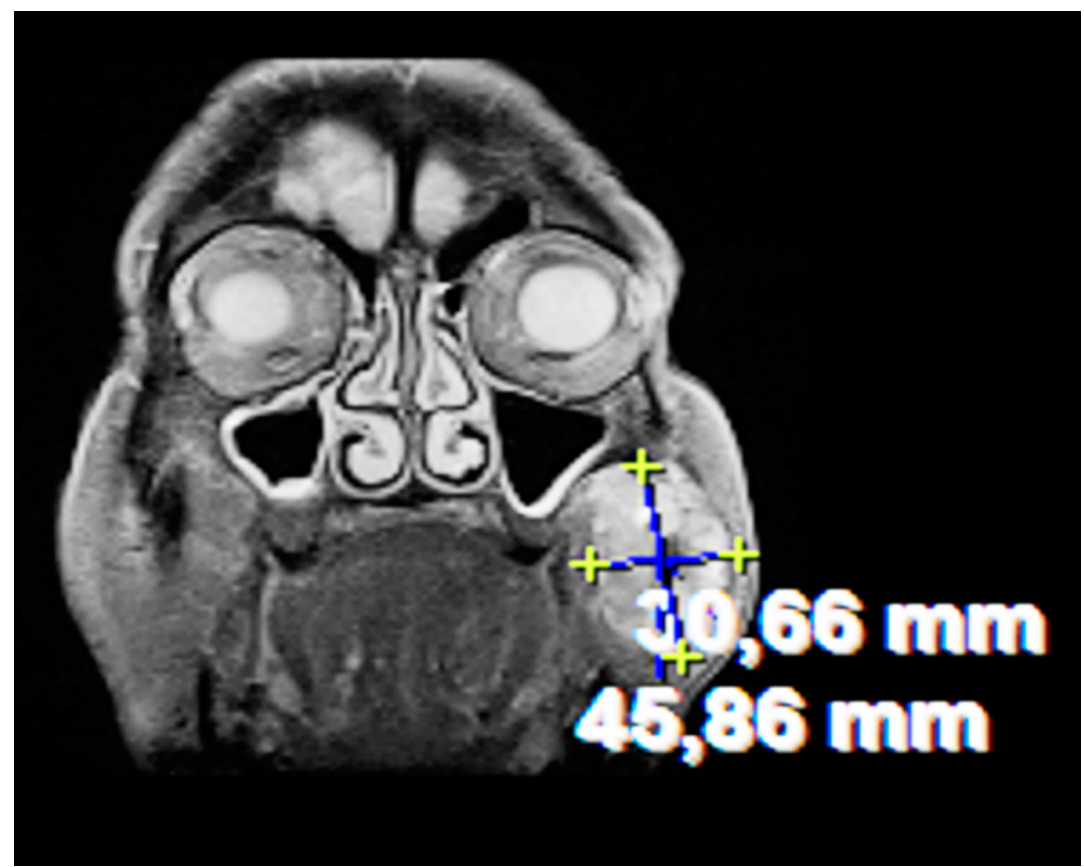

Figure 1. Image of the encapsulated mass located in the left maxillary region, $7 \times 5 \mathrm{~cm}$ in size, causing skin displacement and noninvasive to the surrounding tissues.

painless swelling in the left cheek region. Patient history revealed that the mass had been growing slowly for 5 years, but it had only recently begun to cause regional pain. During this period, he had received various medical treatments but none had alleviated his complaints. In the clinical examination, a subcutaneous solid mass with extraoral expansion on the left cheek region was determined. It did not cause pain with palpation. Other otolaryngological examination was unremarkable. In systemic examination, the patient was found to have left-side hemiplegia due to a previous cerebrovascular event (CVE). No pathological findings were found in routine laboratory examinations. Ultrasonography (USG) examination showed a well-circumscribed solid mass in the left cheek region, while contrast-enhanced magnetic resonance imaging $(\mathrm{MRI})$, revealed a $4.6 \times 3.1 \mathrm{~cm}$ sized mass located in the left maxillary region, between the subcutaneous and posterior masseter muscle, pushing the masseter muscle slightly towards the posterior. It was hypointense in T1, heterogenic hypointense in T2, and had cystic degenerated areas in the central and peripheral regions. The mass was encapsulated, lobulated, well-circumscribed and non-invasive to surrounding tissues (Figure 1). As a result of these findings, surgical excision was planned with a preliminary diagnosis of benign salivary gland tumor. Written informed consent form was obtained from the patient.

As the patient was not suitable for general anesthesia in his current state, the patient's consent was obtained and the operation was performed under local anesthesia. The extraoral route was preferred for better exposure considering the size of the tumor and the patient's age. A horizontal incision was made on the skin considering the facial nerve branches. Following the skin incision, the capsulated, lobulated and well-circumscribed tumor, which started subcutaneously and slightly displaced the masseter muscle, was completely removed along with its capsule (Figure 2). There was no complication during the operation and postoperative period. No recurrence was detected in 6 months follow-up. The follow-up period was 24 months in total.

\section{Histopathological Findings}

Macroscopically; the mass was $5 \times 4 \times 3 \mathrm{~cm}$ in size, lobulated, encapsulated and had hard consistency. When sliced, it was observed that the cross-sectional face was of greyish white color, diffuse and had a homogeneous appearance. Hemotoxylin Eosin (H.E) staining showed that the tumor cells were oval shaped, included vesicular nucleus and eosinophilic cytoplasm and did 


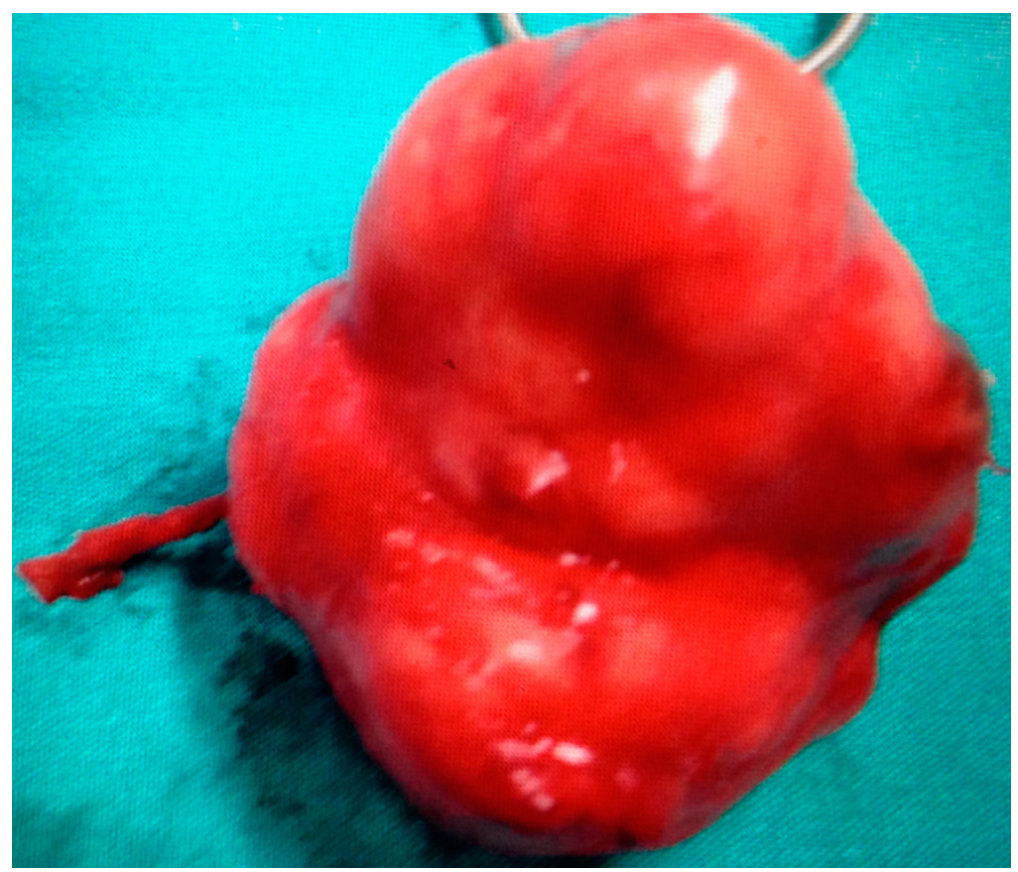

Figure 2. Macroscopic view of extracted material, $5 \times 4 \times 3 \mathrm{~cm}$ size lobular mass.

not show atypia or mitosis. The tumor was determined to be myxoid, had hyaline deposits, small areas of cystic degeneration and wide areas of cartilage.

\section{Discussion}

Pleomorphic adenom is the most common salivary gland tumor affecting the major and minor salivary glands. The parotid gland is the most common occurrence site of PA, with the majority of cases located in the superficial lobe. Occurrence rate of these tumors in minor salivary glands is approximately $8 \%{ }^{4}$. Pleomorphic adenoma is a mixed type benign tumor and its etiology is not exactly known. Genetic studies have identified aberrations and clonal chromosomal anomalies at $8 \mathrm{q} 12$ and $12 \mathrm{q} 15$ in pleomorphic adenomas $^{5}$. In another etiological study, it was said that simian virus (SV40) may play a causal role in the development of pleomorphic adenoma ${ }^{6}$.

Although PA may develop in all age groups, it is often seen in middle-aged and advanced-age patients. Pleomorphic adenomas are tumors that are painless, solid, lobular, slow growing, encapsulated tumors which are non-invasive to the surrounding tissues. Rarely, pleomorphic adenomas of the minor salivary gland may be without a capsule ${ }^{7}$. In our case, the tumor was localized in the left cheek, painless and had a hardrubber-like consistency when palpated. Other findings, such as facial paralysis due to tumor pressure and color changes of the hard palate can be seen. However, these findings were not present in our patient.

In diagnosis; anamnesis, physical examination, radiological examinations and FNAB (fine needle aspiration biopsy) are known to play important roles. In some cases, the tumor can be totally removed without FNAB. In our case, we also preferred the direct excisional biopsy method without performing FNAB; an approach which has been reported in the literature $^{8}$. Depending on the localization, ultrasonography (USG), CT (Computerized Tomography) and MRI can be used as imaging methods. Imaging with CT is usually preferred in order to determine whether there is bone involvement. In our case, we used USG and contrast-enhanced MRI as radiological diagnostic materials. In differential diagnosis, conditions such as, buccal abscess, dermoid cyst, sebaceous cyst, neurofibroma, lipoma, mucoepidermoid carcinoma and low grade polymorphic adenocarcinoma, should be considered and excluded ${ }^{7}$.

Although the risk of malignant transformation is low in pleomorphic adenoma, this possibility is higher 
in patients with PA in the minor salivary glands. The risk of malignant transformation is reported to be $1.6 \%$ in tumors that have developed within 5 years, while this value is increased to $9.4 \%$ for tumors older than 15 years $^{3}$. If PA is ignored, it can reach extremely large sizes and may undergo malignant changes. Clinical findings that suggest malign transformation of a benign PA are: pain, increased mass size and facial paralysis.

The ideal treatment approach is complete removal of the tumor along with its capsule, and to perform long term follow-up as malignant transformation is of concern in such cases. The surgery can be done with external approaches as well as through the oral cavity. This choice may vary depending on the communication between the physician and the patient, aesthetic concerns and the location of the tumor. We preferred external approach because of the patient's age and the size and location of the tumor. We did not detect recurrence in our 2-year follow-up. Recurrence has been reported to occur due to inadequate excision and capsule injury. The recurrence rate of PA has been reported in the literature to range between 2 and 44\%. Extensions of the tumor-called pseudopods-are also thought to play a role in recurrence. As they are resistant to irradiation, radiotherapy is contraindicated ${ }^{7}$.

Facial nerve injury is the most important and problematic complication of this surgery. Although this complication occurs mostly in parotid surgery, the branches of the facial nerve may be subject to injury during submandibular and buccal surgeries. In the current case, no malignant transformations or complications had developed.

\section{Conclusion}

Pleomorphic adenoma of the cheek should be included in the differential diagnosis of masses in this region. It is also important to be aware that facial nerve injury is of concern when the size and location of the PA warrants a higher degree of excision and/or manipulation. Patients should be monitored for the risk of recurrence and malignant transformation with long-term follow-up.

\section{References}

1. Pillai AK, Satpathy M, Nahar S, Moghe S. Pleomorphic Adenoma in Cheek: An Uncommon Finding. IJSS case reports rev 2014;1(1):19-22.

2. Eveson J, Kusafuka K, Stenman G, Nagao T. Tumours of the salivary glands. Barnes L, Eveson JW, Reichart P, Sidransky D, eds. Pathology and Genetics of Head and Neck Tumors. Lyon, France: IARC Press; 2007:254-258.

3. Güney K, Fişenk F, Balkan E, Ağırdır BV, Dinç O. Minör Tükrük Bezlerine ait Pleomorfik Adenoma. Kulak burun boğaz ve baş boyun cerrahisi dergisi 1997;5:34-36.

4. Geetha NT, Deepa BV, Umashankara KV, Kithikumar R. Pleomorphic adenoma of minor salivary gland in the cheek. Int J Oral Health Sci 2015;5:117-20.

5. Kayabaşoğlu G, Kaymaz R, Yılmaz MS. Bukkal bölge yerleşimli pleomorfik adenom. Kulak Burun Boğaz Uygulamaları 2013;1(2):72-74.

6. Martinelli M, Martini F, Rinaldi E, Caramanico L, Magri E, Grandi E, et al. Simian virus 40 sequences and expression of the viral large $\mathrm{T}$ antigen oncoprotein in human pleomorphic adenomas of parotid glands. Am J Pathol 2002;161(4):1127-33.

7. Yegin Y, Celik M, Simsek BV, Olgun B, Sakiz D, Kayhan FT. Bukkal tükürük bezi pleomorfik adenoma: Olgu sunumu. Bozok Med J 2016;1(1):80-3. 